\title{
Analysis of Elevated Temperature Data for Thermodynamic Properties of Selected Radionuclides
}

\author{
D.A. Wruck \\ C.E.A. Palmer
}

August 1997

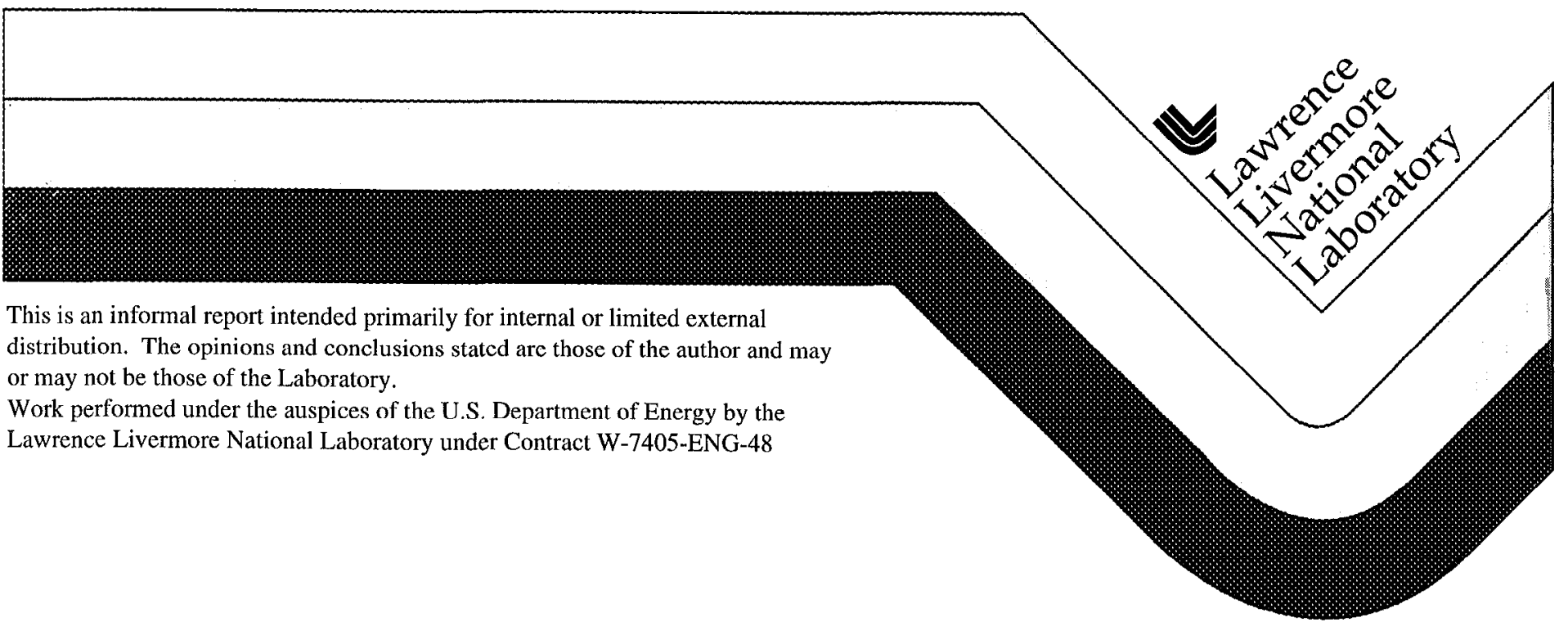




\section{DISCLAIMER}

This document was prepared as an account of work sponsored by an agency of the United States Government. Neither the United States Government nor the University of California nor any of their employees, makes any warranty, express or implied, or assumes any legal liability or responsibility for the accuracy, completeness, or usefulness of any information, apparatus, product, or process disclosed, or represents that its use would not infringe privately owned rights. Reference herein to any specific commercial product, process, or service by trade name, trademark, manufacturer, or otherwise; does not necessarily constitute or imply its endorsement, recommendation, or favoring by the United States Government or the University of California The views and opinions of authors expressed herein do not necessarily state or reflect those of the United States Government or the University of California, and shall not be used for advertising or product endorsement purposes.

This report has been reproduced directly from the best available copy.

Available to DOE and DOE contractors from the Office of Scientific and Technical Information

P.O Box 62, Oak Ridge, TN 37831

Prices available from (423) 576-8401

Available to the public from the National Technical Information Service

U.S. Department of Commerce

5285 Port Royal Rd.

Springfield, VA 22161 


\title{
Analysis of Elevated Temperature Data for Thermodynamic Properties of Selected Radionuclides
}

\author{
David A. Wruck and Cynthia E. A. Palmer \\ Isotope Sciences Division \\ Lawrence Livermore National Laboratory \\ Livermore, CA 94550 \\ Yucca Mountain Project \\ Milestone SPL4B2M4
}

August 1997

\section{Introduction}

This report is a review of chemical thermodynamic data for $\mathrm{Ni}, \mathrm{Zr}, \mathrm{Tc}, \mathrm{U}, \mathrm{Np}, \mathrm{Pu}$ and $\mathrm{Am}$ in aqueous solutions at elevated temperatures. Thermodynamic data for aqueous reactions over the temperature range $20-150^{\circ} \mathrm{C}$ are needed for geochemical modeling studies of the Yucca Mountain Project [96PAL]. The present review is focused on the aqueous complexes relevant to expected conditions in the Yucca Mountain region: primarily the hydroxide, carbonate, sulfate and fluoride complexes with the metal ions. Existing thermodynamic data are evaluated, and means of extrapolating $25^{\circ} \mathrm{C}$ data to the temperatures of interest arc discussed. There will be a separate review of solubility data for relevant $\mathrm{Ni}, \mathrm{Zr}, \mathrm{Tc}, \mathrm{Np}, \mathrm{Pu}$ and Am compounds (milestone SPL4C2M4).

\section{Scope and Methods}

The chemical composition of groundwaters in the vicinity of Yucca Mountain has been discussed in [88DOE] and [96PAL]. The water from well J-13 is thought to be representative of interstitial and fracture waters in the Yucca Mountain region and is used as the reference water in this review. The effect of temperature on the composition of J-13 water in contact with Yucca Mountain tuff has been investigated in several studies [84KNA, $85 \mathrm{KNA} 1,85 \mathrm{KNA} 2,85 \mathrm{OVE}, 86 \mathrm{KNA}, 87 \mathrm{KNA}$ ]. The studies indicate only minor changes in solution composition as the temperature is increased from 25 to $150^{\circ} \mathrm{C}$. The principal changes are an increase in dissolved $\mathrm{Si}$ and a slight decrease in dissolved $\mathrm{Mg}, \mathrm{Ca}$ and carbonate. The $\mathrm{J}-13$ water composition at $25^{\circ} \mathrm{C}$ and the suggested maximum concentrations in interstitial and fracture waters at high temperatures [86GLA] are summarized in Table 1. Expected water compositions in the Yucca Mountain region are the subject of current research [97GLA, 97VIA]. 
Table 1a: Cation concentrations $(\mathrm{mg} / \mathrm{L})$ of reference waters.

\begin{tabular}{cccccccccc}
\hline Water & $\mathrm{Li}$ & $\mathrm{Na}$ & $\mathrm{K}$ & $\mathrm{Mg}$ & $\mathrm{Ca}$ & $\mathrm{Mn}$ & $\mathrm{Fe}$ & $\mathrm{Al}$ & $\mathrm{Si}$ \\
\hline J-13 & 0.06 & 45 & 5.3 & 1.76 & 12 & 0.001 & 0.04 & 0.03 & 30 \\
high temp. & - & $<65$ & $<15$ & $<5$ & $<15$ & - & - & $<5$ & $<160$ \\
\hline
\end{tabular}

Table $1 \mathrm{~b}$ : Anion concentrations $(\mathrm{mg} / \mathrm{L})$ and $\mathrm{pH}$ of reference waters.

\begin{tabular}{cccccccc}
\hline Water & $\mathrm{F}^{-}$ & $\mathrm{Cl}^{-}$ & $\mathrm{NO}_{3}^{-}$ & $\mathrm{HCO}_{3}^{-}$ & $\mathrm{SO}_{4}{ }^{2-}$ & $\mathrm{O}_{2}$ & $\mathrm{pH}$ \\
\hline J-13 & 2.1 & 6.4 & 10 & 143 & 18 & 5.7 & 6.9 \\
high temp. & $<5$ & $<10$ & $<15$ & $<140$ & $<25$ & - & $6.9-7.6$ \\
\hline
\end{tabular}

To prioritize chemical species, we will focus on species for each element $M$ $(\mathrm{M}=\mathrm{Ni}, \mathrm{Zr}, \mathrm{Tc}, \mathrm{U}, \mathrm{Np}, \mathrm{Pu}$ or $\mathrm{Am})$ which account for more than $1 \%$ of the total $\mathrm{M}$ concentration $C_{M}$ in $\mathrm{J}-13$ water spiked with $\mathrm{M}$. Significant species have been identified based on equilibrium calculations using HYDRAQL [88PAP] for $\mathrm{Ni}, \mathrm{Zr}$ and $\mathrm{Tc}$, and EQ3/6 for U, Np, Pu and Am [92PAL]. Anion concentrations in the reference water are approximately independent of temperature, so the temperature dependence of the chemical species distribution for a given element depends on the temperature dependence of the formation constants of the complexes. For inorganic complex formation in aqueous solution, the enthalpy of reaction rarely exceeds $25-30 \mathrm{~kJ} \mathrm{~mol}^{-1}$ [93MAR]. Thus, the formation constant rarely increases by a factor of 10 over the range $25-100^{\circ} \mathrm{C}$ (see Eq. (1) below). In an equilibrium model, the most likely result of a change in temperature is a redistribution among the species which have significant concentrations at $25^{\circ} \mathrm{C}$.

\section{Temperature Extrapolations}

Most of the available thermodynamic data for aqueous reactions has been derived from experiments at or near $25^{\circ} \mathrm{C}$. To model an equilibrium at another temperature, the equilibrium quotient $K^{0}$ is extrapolated from the reference temperature $T_{0}$ to the temperature of interest $T$. Discussions of temperature extrapolation methods for aqueous species and reactions are given in [61PIT, 88SHO, 96STU, 97PUI]. Generally only the simpler methods are appropriate here, due to the limited amount of experimental data for the reactions of interest.

If the enthalpy of reaction $\Delta H^{0}$ is assumed to be constant over the temperature range $T_{0}$ to $T$ (this is equivalent to neglecting the heat capacity of reaction $\Delta C_{p}{ }^{o}$ over the range $T_{0}$ to $T$ ), then the equilibrium constant is approximated by the van't Hoff equation

$$
\log K^{0}(T)=\log K^{0}\left(T_{0}\right)+\frac{\Delta H^{0}\left(T_{0}\right)}{2.303 R}\left(\frac{1}{T_{0}}-\frac{1}{T}\right)
$$

Here $R$ is the gas constant $8.3145 \mathrm{~J} \mathrm{~mol}^{-1} \mathrm{~K}^{-1}$. Eq. (1) is often used over small temperature ranges (about $10 \mathrm{~K}$ or less), because the error due to neglecting $\Delta C_{p}{ }^{o}$ is small compared to the uncertainty in $\log K^{0}\left(T_{0}\right)$. 
Eq. (1) is valid over larger temperature intervals (from about 20 to $200^{\circ} \mathrm{C}$ ) if the reaction is "isoelectric" [38GUR, 88SHO, 97PUI]. An aqueous reaction is defined as isoelectric when the sum of positive charges and the sum of negative charges are the same for reactants and products, for example,

$$
\mathrm{Am}^{3+}+\mathrm{H}_{2} \mathrm{O}=\mathrm{Am}(\mathrm{OH})^{2+}+\mathrm{H}^{+}
$$

In this case Eq. (1) can be used over larger temperature intervals because part of the enthalpy of reaction arises from electrostatic interactions between the reaction species and the solvent water. The dielectric constant of water depends on the temperature, and the electrostatic terms make the dominant contribution to the heat capacity of reaction. For isoelectric reactions, the electrostatic terms tend to cancel, so the heat capacity of reaction is small.

Complexation reactions can often be converted to isoelectric form by combination with acid dissociation reactions. For example, reaction (5) is the sum of reactions (3) and (4):

$$
\begin{aligned}
\mathrm{Am}^{3+}+\mathrm{CO}_{3}{ }^{2-} & =\mathrm{AmCO}_{3}{ }^{+} \\
\mathrm{H}_{2} \mathrm{CO}_{3} & =\mathrm{CO}_{3}{ }^{2-}+2 \mathrm{H}^{+} \\
\mathrm{Am}^{3+}+\mathrm{H}_{2} \mathrm{CO}_{3} & =\mathrm{AmCO}_{3}{ }^{+}+2 \mathrm{H}^{+}
\end{aligned}
$$

If $K_{(X)}{ }^{0}$ and $\Delta H_{(X)}{ }^{0}$ denote the equilibrium constant and enthalpy change for reaction (X), then

$$
\begin{aligned}
\log K_{(S)}{ }^{0}(T) & =\log K_{(3)}{ }^{0}(T)+\log K_{(4)}{ }^{0}(T) \\
\Delta H_{(5)}{ }^{0}(T) & =\Delta H_{(3)}{ }^{0}(T)+\Delta H_{(4)}{ }^{0}(T)
\end{aligned}
$$

Acid dissociation data have been determined for the complexes of interest, and uncertainties in the acid constants are $\leq 0.03$ log units over the range $20-100^{\circ} \mathrm{C}$. Data for the acid dissociation reactions can be found in the following references: $\mathrm{H}_{2} \mathrm{O}$ [81MAR], $\mathrm{H}_{2} \mathrm{CO}_{3}$ [82PLU,82PAT,84PAT], $\mathrm{HF}$ [63ELL], $\mathrm{H}_{2} \mathrm{SO}_{4}$ and $\mathrm{H}_{3} \mathrm{PO}_{4}$ [86SMI].

Using the example above, if experimental values of $\log K_{(3)}{ }^{o}$ are available at several temperatures, a two-parameter fit to the data can be made using Eqs. (1) and (6).

Alternatively, if experimental values of $\log K_{(3)}{ }^{\circ}\left(T_{0}\right)$ and $\Delta H_{(3)}{ }^{\circ}\left(T_{0}\right)$ are available, Eqs. (6) and (7) at $T=T_{0}$ determine $\log K_{(5)}{ }^{\circ}\left(T_{0}\right)$ and $\Delta H_{(5)}{ }^{\circ}\left(T_{0}\right)$, which can then be substituted in Eq. (1).

If $\Delta C_{p}{ }^{0}$ is treated as a nonzero constant over the temperature range $T_{0}$ to $T$, the expression for the equilibrium constant is

$$
\log K^{0}(T)=\log K^{0}\left(T_{0}\right)+\frac{\Delta H^{0}\left(T_{0}\right)}{2.303 R}\left(\frac{1}{T_{0}}-\frac{1}{T}\right)+\frac{\Delta C_{p}^{0}}{2.303 R}\left(\frac{T_{0}}{T}-1+\ln \frac{T}{T_{0}}\right)
$$

There is sufficient experimental data to determine $\Delta C_{p}{ }^{0}$ for only a few of the reactions of interest. Estimates of $\Delta C_{p}{ }^{0}$ based on the Criss-Cobble method have been made for some of the $\mathrm{U}$ and $\mathrm{Pu}$ reactions [80LEM].

\section{4. $\mathbf{N i}$}

$\mathrm{Ni}$ is very soluble (to about $0.1 \mathrm{~m}$ ) as $\mathrm{Ni}(\mathrm{II})$ in $\mathrm{J}-13$ water at $25^{\circ} \mathrm{C}$. The solubilitycontrolling solid is $\mathrm{Ni}(\mathrm{OH})_{2}$, so the $\mathrm{Ni}$ solubility is sensitive to $\mathrm{pH}$. Significant aqueous 
species are $\mathrm{Ni}^{2+}\left(97 \%\right.$ of $\left.\mathrm{C}_{\mathrm{Ni}}\right)$ and $\mathrm{NiSO}_{4}{ }^{0}\left(3 \%\right.$ of $\left.\mathrm{C}_{\mathrm{Ni}}\right)$. These conclusions are based on the equilibrium constants selected in [93MAR].

The complex formation reaction $\mathrm{Ni}^{2+}+\mathrm{SO}_{4}{ }^{2-}=\mathrm{NiSO}_{4}{ }^{0}$ has been investigated by calorimetry at temperatures near $25^{\circ} \mathrm{C}$ [59NAI, 69IZA, 73POW] and by electrical conductivity measurements over the range 0 to $45^{\circ} \mathrm{C}$ [73KAT]. Thermodynamic constants have been calculated from heat of dilution data [70LAR]. A study of the complexation reaction was made by ultraviolet absorption in $5 \mathrm{M}$ perchlorate media and temperatures in the range 25 to $70^{\circ} \mathrm{C}$, but the precision was low and extrapolation of the results to low ionic strength is subject to large errors [77ASH]. The experimental results are listed in Table 2. There is a large spread in the values of $\Delta H^{0}$. The value of $\Delta H^{0}$ selected in [93MAR] is also listed in Table 2. If the smallest experimental values of $\Delta H^{0}$ are correct, there is practically no change in the $\mathrm{Ni}$ speciation over the range $25-150^{\circ} \mathrm{C}$. If the largest experimental value of $\Delta H^{0}$ is correct, there is a modest increase in the $\mathrm{NiSO}_{4}{ }^{0}$ concentration as the temperature increases, and $\mathrm{NiSO}_{4}{ }^{0}$ accounts for roughly $10 \%$ of $\mathrm{C}_{\mathrm{Ni}}$ at $100^{\circ} \mathrm{C}$.

Table 2: Thermodynamic data for the reaction $\mathrm{Ni}^{2+}+\mathrm{SO}_{4}{ }^{2-}=\mathrm{NiSO}_{4}{ }^{0}$.

\begin{tabular}{cccc}
\hline Method & $\log K^{0}$ & $\Delta H^{0}, \mathrm{~kJ} \mathrm{~mol}^{-1}$ & Reference \\
\hline calorimetry & 2.32 & 13.9 & [59NAI] \\
calorimetry & $2.81 \pm 0.09$ & $1.72 \pm 0.08$ & [69IZA] \\
calorimetry & not stated & $1.75 \pm 0.15$ & [73POW] \\
conductivity & 2.27 & 5.3 & [73KAT] \\
heat of dilution & $2.30 \pm 0.04$ & $6.4 \pm 0.8$ & [70LAR] \\
tabulated data & $2.34 \pm 0.06$ & 5.8 & [93MAR] \\
\hline
\end{tabular}

The hydrolysis of $\mathrm{Ni}^{2+}$ has been investigated by solubility studies of $\mathrm{NiO}$ to $300^{\circ} \mathrm{C}$ [80TRE]. Equilibrium quotients for the formation of $\mathrm{NiOH}^{+}, \mathrm{Ni}(\mathrm{OH})_{2}{ }^{0}$, and $\mathrm{Ni}(\mathrm{OH})_{3}{ }^{-}$ were determined over the temperature range 20 to $300^{\circ} \mathrm{C}$. Although hydrolysis becomes more pronounced at higher temperatures, hydrolyzed Ni(II) species are not significant at temperatures below $150^{\circ} \mathrm{C}$ and $\mathrm{pH}<9$.

Calorimetric studies of the formation of $\mathrm{NiF}^{+}$have been made in $0.5 \mathrm{M}$ nitrate medium [74ARU], $3 \mathrm{M}$ perchlorate medium [76KUL] and 0.1 to $3 \mathrm{M}$ perchlorate media [81KUL]. The results indicate the enthalpy of reaction is small at low ionic strengths. We estimate that $\Delta H^{0}$ is between 0 and $3 \mathrm{~kJ} \mathrm{~mol}^{-1}$, and $\mathrm{NiF}^{+}$does not become significant under expected conditions.

The value of $\log K^{0}$ for the formation of $\mathrm{NiHPO}_{4}{ }^{0}$ is about 2 [67SIG, 72FRE]. Phosphate concentrations are very low in waters of the Yucca Mountain region, so Ni(II) phosphate complexes are not significant under the conditions of interest.

The Ni species in aqueous solutions under expected repository conditions are relatively well-understood. It is most likely that $\mathrm{Ni}^{2+}$ remains the dominant species over the temperature range of interest. The most significant gap is the lack of data on the formation of $\mathrm{NiCO}_{3}{ }^{0}$ at elevated temperatures. 
At $25^{\circ} \mathrm{C}$ the equilibrium $\mathrm{Zr}$ concentration in $\mathrm{J}-13$ water is less than $10^{-8} \mathrm{~m}$ due to the low solubility of $\mathrm{ZrO}_{2}$. Likely solution species are $\mathrm{Zr}(\mathrm{OH})_{4}{ }^{\circ}$, and at higher $\mathrm{pH}$ values, $\mathrm{Zr}(\mathrm{OH})_{5}^{-}$. Stability constants for $\mathrm{Zr}(\mathrm{IV})$ carbonate and phosphate complexes were not available, so their values were estimated from data for quadrivalent actinides.

In a review of data to 1992, a self-consistent set of thermodynamic constants was listed for $\mathrm{Zr}, \mathrm{ZrO}_{2}$ and $\mathrm{Zr}(\mathrm{OH})_{4}$ solids, aqueous $\mathrm{Zr}^{4+}$ and the $\mathrm{Zr}(\mathrm{IV})$ hydrolysis species [92SLO]. The thermodynamic constants listed for the hydrolysis species were estimates based on limited experimental data. Understanding of $\mathrm{Zr}(\mathrm{IV})$ hydrolysis behavior is largely derived from solubility experiments and distribution experiments (extraction or ion exchange). Interpretation of the experimental results is complicated by the tendency of $\mathrm{Zr}$ (IV) to form polynuclear species or colloids and errors due to extrapolation of high ionic strength data to standard conditions. One study has been made near $25^{\circ} \mathrm{C}$ by spectrophotometry of competing complexes in $0.1 \mathrm{M}$ perchlorate and nitrate media [69NAZ].

Thermodynamic functions for $\mathrm{Zr}$ (IV) fluoride complex formation in $4 \mathrm{M}$ perchlorate medium have been determined from stability constant and calorimetric measurements [90AHR]. The experiments illustrate a fundamental problem in the study of $\mathrm{Zr}$ (IV) complexes (which also applies to Tc(IV) and actinide(IV) complexes). To avoid hydrolysis of $\mathrm{Zr}^{4+}$, measurements must be performed in a strongly acid medium of high ionic strength, and extrapolation of the data to low ionic strength is subject to large errors. The alternative is to perform experiments in low ionic strength media and include hydrolysis in the data analysis, but then errors in the hydrolysis constants affect the results.

Stability constants for $\mathrm{Zr}$ (IV) sulfate complexes are fairly well-known at high ionic strength and $25^{\circ} \mathrm{C}$, but no data was found for the elevated temperature behavior. No experimental data was found for $\mathrm{Zr}$ (IV) carbonate or phosphate complex formation.

There is only a small amount of data available for $\mathrm{Zr}(\mathrm{IV})$ hydrolysis and complex formation under expected repository conditions. This is partly due to the practical difficulties mentioned above. The $\mathrm{Zr}$ solubility is likely to remain low under conditions of interest, so a detailed understanding of the complexation behavior may not be necessary. A more limited set of solubility experiments may establish that maximum $\mathrm{Zr}$ concentrations are very small under expected repository conditions.

A review of the chemical thermodynamics of $\mathrm{Ni}$ and $\mathrm{Zr}$ is currently being conducted by the Yucca Mountain Project and will result in a database for $\mathrm{Ni}$ and $\mathrm{Zr}$ which is internally consistent with the Nuclear Energy Agency Themodynamic Data Base (NEA-TDB) data for Tc, U [92GRE, 95GRE], Np, Pu and Am [95SIL].

\section{Tc}

Tc is highly soluble as pertechnetate ion $\mathrm{TcO}_{4}^{-}$in $\mathrm{J}-13$ water at $25^{\circ} \mathrm{C}$. $\mathrm{TcO}_{4}^{-}$is probably the only significant aqueous Tc species under J-13 conditions. $\mathrm{HTcO}_{4}$ is a strong acid. There is not much data on pertechnetate complexes in aqueous solution, but based 
on ion charge to radius ratios, the pertechnetate complexes are expected to be much weaker than the corresponding hydroxide, fluoride, sulfate, or carbonate complexes.

$\mathrm{The} \mathrm{Tc}(\mathrm{VII}) / \mathrm{Tc}(\mathrm{IV})$ redox equilibrium has a critical effect on the behavior of Tc under expected repository conditions [96PAL]. At $25^{\circ} \mathrm{C}$ and reducing conditions such as USW H-3, the Tc concentration is limited to low values $\left(<10^{-7} \mathrm{~m}\right)$ by the solubility of $\mathrm{TcO}_{2} \cdot \mathrm{xH}_{2} \mathrm{O}$. Under oxic conditions such as $\mathrm{J}-13$, the Tc solubility is high and is controlled by pertechnetate salts [84KER].

$\mathrm{The} \mathrm{Tc}(\mathrm{VII}) / \mathrm{Tc}$ (IV) redox equilibrium has been investigated by emf measurements of $\mathrm{TcO}_{2} \cdot \mathrm{xH}_{2} \mathrm{O}$ electrodes in contact with $\mathrm{TcO}_{4}^{-}$solutions at $24-25^{\circ} \mathrm{C}$ [53COB, 55CAR, 91MEY]. The reaction can be written as

$$
\mathrm{TcO}_{4}^{-}+4 \mathrm{H}^{+}+3 \mathrm{e}^{-}=\mathrm{TcO}_{2} \cdot x \mathrm{H}_{2} \mathrm{O}(\mathrm{s})+(2-x) \mathrm{H}_{2} \mathrm{O}
$$

The Nernst equation for reaction (9) is

$$
E=E^{0}+\frac{2.303 R T}{3 F}\left(\log a\left(\mathrm{TcO}_{4}^{-}\right)-4 \mathrm{pH}\right)
$$

$E$ is the potential, $R$ is the ideal gas constant, $F$ is the Faraday constant, and $a\left(\mathrm{TcO}_{4}{ }^{-}\right)$is the $\mathrm{TcO}_{4}^{-}$activity. The standard potential $E^{0}$ is $0.75 \pm 0.02 \mathrm{~V}$ [91MEY]. The Nernstian behavior has been verified as a function of $\mathrm{pH}$ and $\mathrm{TcO}_{4}{ }^{-}$activity, but not temperature.

There is little or no data available on the temperature dependence of Tc complexation reactions in aqueous solutions. However, the $\mathrm{Tc}(\mathrm{VII}) / \mathrm{Tc}(\mathrm{IV})$ redox equilibrium has a strong effect on the Tc solubility and is likely to be the critical issue for repository modeling. The $\mathrm{Tc}(\mathrm{VII}) / \mathrm{Tc}(\mathrm{IV})$ redox behavior is relatively well-understood at $25^{\circ} \mathrm{C}$. The validity of temperature extrapolations using the Nernst equation could be verified by emf measurements on $\mathrm{TcO}_{2} \cdot \mathrm{xH}_{2} \mathrm{O}$ electrodes at a number of temperatures. High carbonate or $\mathrm{Si}$ concentrations may alter the $\mathrm{TcO}_{2} \cdot \mathrm{xH}_{2} \mathrm{O}$ surface and this could be checked by measurements in various solutions. A small number of Tc solubility experiments in reference waters may also help verify the expected behavior.

The NEA-TDB review of the chemical thermodynamics of Tc is in preparation.

\section{U}

$\mathrm{U}$ is sparingly soluble (to about $10^{-6} \mathrm{~m}$ ) as $\mathrm{U}(\mathrm{VI})$ in $\mathrm{J}-13$ water at $25^{\circ} \mathrm{C}$. Significant aqueous species are $\mathrm{UO}_{2}\left(\mathrm{CO}_{3}\right)_{2}{ }^{2-}$ (about $90 \%$ of $\mathrm{C}_{\mathrm{U}}$ ), $\mathrm{UO}_{2}\left(\mathrm{CO}_{3}\right)_{3}{ }^{4-}$ and $\mathrm{UO}_{2} \mathrm{CO}_{3}{ }^{\circ}$ (each about $5 \%$ of $\mathrm{C}_{\mathrm{U}}$ ).

The temperature dependence of the formation reactions for the U(VI) carbonate complexes has been determined based on calorimetric studies and measurements of the solubility of $\mathrm{UO}_{2} \mathrm{CO}_{3}$ to $200^{\circ} \mathrm{C}$. Discussions of the original references and interpretation of the experimental data are available in the U NEA-TDB review [92GRE, 95GRE]. The $\mathrm{UO}_{2} \mathrm{CO}_{3}{ }^{\circ}$ data is also analyzed in [97PUI]. Enthalpy data or elevated temperature formation constant data are also available for U(VI) hydrolysis species, sulfate complexes and fluoride complexes [92GRE]. At low U concentrations, the U(VI) hydrolysis species, sulfate complexes and fluoride complexes are not expected to be significant compared to the U(VI) carbonate complexes under the conditions of interest.

A recent study of the interaction of $U(V I)$ and silicic acid in aqueous solutions by time-resolved laser-induced fluorescence spectroscopy has suggested that the complexes 
may be significant under expected repository conditions [97MOL]. The interaction was described by the reaction

$$
\mathrm{UO}_{2}{ }^{2+}+\mathrm{Si}(\mathrm{OH})_{4}{ }^{0}=\mathrm{UO}_{2} \mathrm{OSi}(\mathrm{OH})_{3}{ }^{+}+\mathrm{H}^{+}
$$

The stability constant for reaction (11) was determined to be $\log K^{0}=-1.60 \pm 0.36$, which indicates that the reaction would be competitive with carbonate complex formation under the conditions of interest. Smaller values of the stablity constant have been determined in earlier studies: $\log K^{0}=-2.25 \pm 0.13$ [71POR] and $\log K^{0}=-2.70 \pm 0.34$ [92SAT]. There is no elevated temperature data for the interaction of U(VI) and silicic acid.

The aqueous $U$ species under expected repository conditions are relatively wellunderstood, with the exception of the U(VI)-silicic acid interaction. Si concentrations are relatively high in the reference waters and are expected to increase with temperature, so a better understanding of the interaction of $U(V I)$ and silicic acid at elevated temperatures is needed.

\section{Np}

The maximum $\mathrm{Np}$ concentration in J-13 water at $25^{\circ} \mathrm{C}$ is on the order of $10^{-4} \mathrm{~m}$ and is limited by the solubility of $\mathrm{NaNpO}_{2} \mathrm{CO}_{3} \cdot \mathrm{xH}_{2} \mathrm{O}$, at least over time scales of a few months or less. Significant aqueous species are $\mathrm{NpO}_{2}{ }^{+}$(about $90 \%$ of $\mathrm{C}_{\mathrm{Np}}$ ) and $\mathrm{NpO}_{2} \mathrm{CO}_{3}{ }^{-}$ (about $10 \%$ of $\mathrm{C}_{\mathrm{Np}}$ ).

The $\mathrm{NpO}_{2} \mathrm{CO}_{3}{ }^{-}$formation reaction has been investigated by solubility studies of sodium and potassium neptunyl carbonates to $75^{\circ} \mathrm{C}$ [93LEM] and by near-infrared (nir) absorption spectroscopy to $70^{\circ} \mathrm{C}$ [95TAI, 96CLA]. The results are listed in Table 3 with estimated uncertainties. In [93LEM] the solubility data were analyzed using two models labeled $\mathrm{A}$ and $\mathrm{B}$. We have extrapolated the nir data to $75^{\circ} \mathrm{C}$ for easier comparison. The solubility studies indicate $\Delta H$ is positive, but the nir work indicates $\Delta H$ is negative. The difference may be an ionic strength effect, or possibly the use of tetrabutylammonium salts affected the nir results. It is difficult to assess the nir data because few experimental details were provided in [95TAI, 96CLA]. Direct measurements on Np-spiked J-13 water at temperatures up to $90^{\circ} \mathrm{C}$ have indicated that the $\mathrm{Np}(\mathrm{V})$ carbonate complex is significant at elevated temperatures [93NIT].

Table 3: Experimental $\log \mathrm{K}$ values for the reaction $\mathrm{NpO}_{2}{ }^{+}+\mathrm{CO}_{3}{ }^{2-}=\mathrm{NpO}_{2} \mathrm{CO}_{3}{ }^{-}$.

\begin{tabular}{cccc}
\hline $\mathrm{T},{ }^{\circ} \mathrm{C}$ & $\begin{array}{c}{[93 \mathrm{LEM}] \text { model A }} \\
(\mathrm{I}=1 \mathrm{M})\end{array}$ & $\begin{array}{c}{[93 \mathrm{LEM}] \text { model B }} \\
(\mathrm{I}=1 \mathrm{M})\end{array}$ & $\begin{array}{c}{[96 \mathrm{CLA}]} \\
(\mathrm{I}=0.1 \mathrm{M})\end{array}$ \\
\hline 25 & $4.6 \pm 0.1$ & - & $4.1 \pm 0.2$ \\
50 & $5.6 \pm 0.1$ & $5.6 \pm 0.2$ & $3.9 \pm 0.2$ \\
75 & $5.2 \pm 0.3$ & $6.0 \pm 0.7$ & $3.7 \pm 0.3$ \\
\hline
\end{tabular}

Calorimetric measurements of the enthalpy of reaction for formation of the hydrolysis product $\mathrm{NpO}_{2} \mathrm{OH}^{0}$ have been reported [91SUL]. The formation of $\mathrm{NpO}_{2} \mathrm{OH}^{0}$ 
has been investigated by nir absorption spectroscopy to $70^{\circ} \mathrm{C}$, but very few experimental details were given [95TAI].

A better understanding of the $\mathrm{NpO}_{2} \mathrm{CO}_{3}{ }^{-}$formation reaction at elevated temperatures is needed. There is also a need for improved understanding of the $\mathrm{Np}(\mathrm{V}) / \mathrm{Np}$ (IV) solid state transformation kinetics, but this is outside the scope of the present report and is discussed in the solubility report.

\section{Pu}

$\mathrm{Pu}$ is sparingly soluble (to about $10^{-7} \mathrm{~m}$ ) in J-13 water at $25^{\circ} \mathrm{C}$. Significant aqueous species include $\mathrm{PuO}_{2}{ }^{+}, \mathrm{PuO}_{2} \mathrm{CO}_{3}{ }^{0}$ and $\mathrm{PuO}_{2}\left(\mathrm{CO}_{3}\right)_{2}{ }^{2-}$. Identification of $\mathrm{Pu}$ species in reference waters is complicated by the redox chemistry of $\mathrm{Pu}$, the limited amount of data for aqueous $\mathrm{Pu}(\mathrm{IV})$ species and the tendency of $\mathrm{Pu}(\mathrm{IV})$ to form colloidal hydrous oxides.

Measurements on J-13 water spiked with $\mathrm{Pu}^{4+}$ indicate that the $\mathrm{Pu}$ concentration decreases from about $10^{-7} \mathrm{~m}$ at $25^{\circ} \mathrm{C}$ to about $10^{-8} \mathrm{~m}$ at $90^{\circ} \mathrm{C}$ [93NIT]. The observed decrease in $\mathrm{Pu}$ concentrations with temperature may have been a kinetics effect rather than a true temperature-dependent solubility effect, because the precipitates were lowcrystallinity mixtures of $\mathrm{Pu}(\mathrm{IV})$ hydrous oxide and $\mathrm{Pu}$ carbonates. Experiments in which $\mathrm{Pu}$ was introduced as $\mathrm{Pu}^{4+}, \mathrm{PuO}_{2}{ }^{+}$or $\mathrm{PuO}_{2}{ }^{2+}$ to dilute bicarbonate solutions at $\mathrm{pH} 6$ have been reported [93NEU]. The dominant aqueous $\mathrm{Pu}$ species was $\mathrm{PuO}_{2}{ }^{+}$in the $\mathrm{PuO}_{2}{ }^{+}$and $\mathrm{PuO}_{2}{ }^{2+}$ experiments. In the $\mathrm{Pu}^{4+}$ experiments the $\mathrm{Pu}$ concentration was very low and the solution species were not determined.

Enthalpy data for $\mathrm{Pu}(\mathrm{VI})$ carbonate complexation is available [82SUL, 88ULL]. The U(VI) carbonate complexes should be good analogs for $\mathrm{Pu}(\mathrm{VI})$ carbonate complexes, because the entropy difference due to electron configuration is small. It is difficult to perform direct studies of $\mathrm{PuO}_{2} \mathrm{CO}_{3}{ }^{-}$at elevated temperatures due to rapid disproportionation of $\mathrm{Pu}(\mathrm{V})$ to low-solubility $\mathrm{Pu}(\mathrm{IV})$ and $\mathrm{Pu}(\mathrm{VI})$ forms, so an improved understanding of $\mathrm{NpO}_{2} \mathrm{CO}_{3}{ }^{-}$would also be valuable as an analog for $\mathrm{PuO}_{2} \mathrm{CO}_{3}{ }^{-}$. No data was found for the temperature behavior of $\mathrm{Pu}(\mathrm{IV})$ carbonate complexation, but there is enthalpy data for the formation of $\mathrm{U}\left(\mathrm{CO}_{3}\right)_{5}{ }^{6-}$ [92GRE].

The chemistry of $\mathrm{Pu}$ in natural waters can be quite complex, involving slow $\mathrm{Pu}(\mathrm{V}) / \mathrm{Pu}(\mathrm{IV})$ and $\mathrm{Pu}(\mathrm{VI}) / \mathrm{Pu}(\mathrm{IV})$ solid-state transformation reactions, polymeric or colloidal $\mathrm{Pu}(\mathrm{IV})$ forms and strong sorption to mineral or humic material. There is some experimental evidence that indicates $\mathrm{PuO}_{2}{ }^{+}$is the dominant dissolved species under nearneutral $\mathrm{pH}$ conditions in the absence of strong complexing agents. Due to practical difficulties in the direct study of $\mathrm{Pu}(\mathrm{V})$ complexes at elevated temperatures, it will probably be necessary to estimate $\mathrm{Pu}(\mathrm{V})$ complexation behavior based on $\mathrm{Np}(\mathrm{V})$ analogs.

The NEA-TDB review of the chemical thermodynamics of $\mathrm{Np}$ and $\mathrm{Pu}$ is in preparation. 


\section{Am}

The Am concentration in $\mathrm{J}-13$ water at $25^{\circ} \mathrm{C}$ is limited to about $10^{-7} \mathrm{~m}$ by the solubility of $\mathrm{AmOHCO}_{3}$. Significant aqueous species are $\mathrm{AmCO}_{3}{ }^{+}$(about $75 \%$ of $\mathrm{C}_{\mathrm{Am}}$ ), $\mathrm{AmOH}^{2+}$ (about $20 \%$ of $\mathrm{C}_{\mathrm{Am}}$ ) and $\mathrm{Am}^{3+}$ (about $5 \%$ of $\mathrm{C}_{\mathrm{Am}}$ ).

The $\mathrm{AmCO}_{3}{ }^{+}$formation reaction has been investigated by laser-induced photoacoustic spectroscopy to $75^{\circ} \mathrm{C}$ [96WRU]. In Table 4, the experimental data have been extrapolated to zero ionic strength and analyzed by the isoelectric method discussed in section 3 of this report. Data for reaction (4) is from [82PLU,82PAT, 84PAT]. The result of the analysis is $\Delta H_{(5)}{ }^{0}=66 \pm 10 \mathrm{~kJ} / \mathrm{mol}$.

Table 4: Formation constants for reactions (3), (4) and (5).

\begin{tabular}{cccc}
\hline$T,{ }^{\circ} \mathrm{C}$ & $\log K_{(3)}{ }^{0}(T)$ & $\log K_{(4)}{ }^{0}(T)$ & $\log K_{(5)}{ }^{0}(T)$ \\
\hline 25 & $7.54 \pm 0.12$ & -16.686 & $-9.14 \pm 0.12$ \\
50 & $8.02 \pm 0.12$ & -16.459 & $-8.44 \pm 0.12$ \\
75 & $8.95 \pm 0.43$ & -16.422 & $-7.47 \pm 0.43$ \\
\hline
\end{tabular}

No experimental data was found for the temperature dependence of the $\mathrm{AmOH}^{2+}$ formation reaction. There is enthalpy data for the rare-earth analog $\mathrm{SmOH}^{2+}$ [93MAR]. The Am(III) hydrolysis behavior could be investigated by solubility studies of $\mathrm{Am}(\mathrm{OH})_{3}$ at clevated temperatures.

\section{FY97 Experiments}

In the mid-year report (milestone SPLAB1M4) we identified the limited number of direct measurements at higher temperatures as an area of need and proposed to extend our investigation of $\mathrm{AmCO}_{3}{ }^{+}$complexation by laser-induced photoacoustic spectroscopy to temperatures above $75^{\circ} \mathrm{C}$. Analysis of the earlier experiments suggested that much of the uncertainty at $75^{\circ} \mathrm{C}$ could be traced to loss of $\mathrm{CO}_{2}$ from the samples, therefore we have developed a photoacoustic cell that can be sealed and maintained at temperatures from 25 to $150^{\circ} \mathrm{C}$. The cell body was constructed from commercially available high pressure chromatography fittings. The quartz windows, piezoelectric transducer and cell heater assemblies were fabricated in-house. The wetted parts are fused silica, Ti and a graphitefilled polyimide which has been treated at high temperatures. The sample volume is 0.2 $\mathrm{mL}$. The cell has been tested with deionized water and dilute $\mathrm{Nd}(\mathrm{III})$ solutions to $155^{\circ} \mathrm{C}$. The Am(III) carbonate experiments have not been completed, however, work is in progress and we expect to have results by the end of FY97. 


\section{Summary}

Reasonably accurate temperature extrapolations can be made for a number of species of interest $\left(\mathrm{NiSO}_{4}{ }^{\circ}\right.$, the $\mathrm{U}(\mathrm{VI})$ carbonate complexes, $\left.\mathrm{AmCO}_{3}{ }^{+}\right)$, i.e., the estimated uncertainty in $\log K^{\circ}$ over the range $20-150^{\circ} \mathrm{C}$ is about 0.5 . Analog data is available for some species which lack direct measurements ( $\mathrm{Pu}$ carbonates and $\mathrm{AmOH}^{2+}$ ). Several areas of need have been identified, including an improved understanding of Tc redox behavior and the formation of $\mathrm{NpO}_{2} \mathrm{CO}_{3}{ }^{-}$at elevated temperatures. There are very few direct measurements at temperatures above $75^{\circ} \mathrm{C}$. Of the significant species identified, such data are only available for the U(VI) carbonate complexes. 


\section{References}

[38GUR] Gurney, R.W., Exchange forces and electrostatic forces between ions in solution, J. Chem. Phys. 6, 499 (1938).

[53COB] Cobble, J.W., Smith, W.T., Boyd, G.E., Thermodynamic properties of technetium and rhenium compounds: II. Heats of formation of technetium heptoxide and pertechnetic acid, potential of the technetium(IV)technetium(VII) couple and a potential diagram for technetium, J. Am. Chem. Soc. 75, 5777 (1953).

[55CAR] Cartledge, G.H, Smith, W.T., Revision of the electrode potential diagram for technetium, J. Phys. Chem. 59, 1111 (1955).

[59NAI] Nair, V.S.K., and Nancollas, G.H., J. Chem. Soc. 1959, 3934 (1959).

[61PIT] Pitzer, K.S., and Brewer, L., Thermodynamics, 2nd edition, McGraw-Hill, New York, 1961.

[63ELL] Ellis, A.J., The effect of temperature on the ionization of hydrofluoric acid, J. Chem. Soc. 1963, 4300 (1963).

[67SIG] Sigel, H., Becker, K., McCormick, D., Biochim. Biophys. Acta 148, 655 (1967).

[69IZA] Izatt, R.M., J. Chem. Soc. A 1969, 47 (1969).

[69NAZ] Nazarenko, V.A., Mandzhgaladze, O.V., Zh. Neorg. Khim. 14, 1219 (1969).

[70LAR] Larson, J.W., Thermodynamics of divalent metal sulfate dissociation and the structure of the solvated metal sulfate ion pair, J. Phys. Chem. 74, 3392 (1970).

[71POR] Porter, R.A., Weber, W.J., The interaction of silicic acid with iron(III) and uranyl ions in dilute aqueous solution, J. Inorg. Nucl. Chem. 33, 2443 (1971).

[72FRE] Frey, C.M., Stuehr, J.E., J. Amer. Chem. Soc. 94, 8898 (1972).

[72SER] Sergeyeva, E.I., Nikitin, A.A., Khodakovsky, I.L., Naumov, G.B., Vernadskiy, V.I., Experimental investigation of equilibria in the system $\mathrm{UO}_{3}-\mathrm{CO}_{2}-\mathrm{H}_{2} \mathrm{O}$ in $25-200^{\circ} \mathrm{C}$ temperature interval, Geochim. Int. 11, 900 (1972).

[73KAT] Katayama, S., Conductometric determination of ion-association constants for magnesium and nickel sulfates in aqueous solutions at various 
temperatures between $0^{\circ} \mathrm{C}$ and $45^{\circ} \mathrm{C}$, Bull. Chem. Soc. Japan 46, 106 (1973).

[73POW] Powell, H.K.J., J. Chem. Soc. Dalton Trans. 1973, 1947 (1973).

[74ARU] Aruga, R., Calorimetric study of the association of fluoride ion with several bivalent metal ions, Ann. Chim. (Rome) 64, 439 (1974).

[76BAE] Baes, C.F, Mesmer, R.E., The hydrolysis of cations, Wiley-Interscience, New York, 1976.

[76KUL] Kul'vinova, L.A., Blokhin, V.V., Mironov, V.E., Thermodynamic properties of certain transition fluoride complexes in aqueous salt solutions, Zh. Fiz. Khim. 50, 1287 (1976).

[77ASH] Ashurst, K.G., Hancock, R.D., Characterization of inner- and outer-sphere complexes by thermodynamics and absorption spectra. Part 1 . Sulphatocomplexes of the first-row transition elements, J. Chem. Soc. Dalton 1977, 1701 (1977).

[80LEM] Lemire, R.J., and Tremaine, P.R., Uranium and plutonium equilibria in aqueous solutions to $200^{\circ} \mathrm{C}$, J. Chem. Eng. Data 25, 361 (1980).

[80TRE] Tremaine, P.R., Leblanc, J.C., The solubility of nickel oxide and hydrolysis of $\mathrm{Ni}^{2+}$ in water to $573 \mathrm{~K}, \mathrm{~J}$. Chem. Thermodynamics 12, $521(1980)$.

[81KUL] Kul'vinova, L.A., Blokhin, V.V., Makashev, Y.A., Mironov, V.E., Thermodynamics of the formation of fluoride complexes of transition metals in water-salt solutions, Soviet J. Coord. Chem. 7, 104 (1981).

[81MAR] Marshall, W.L., Franck, E.U., Ion product of water substance, $0-1000^{\circ} \mathrm{C}$, 1-10,000 bars, new international formulation and its background, J. Phys. Chem. Ref. Data 10, 295 (1981).

[82PAT] Patterson, C.S., Slocum, G.H., Busey, R.H., Mesmer, R.E., Carbonate equilibria in hydrothermal systems: first ionization of carbonic acid in $\mathrm{NaCl}$ media to $300^{\circ} \mathrm{C}$, Geochim. Cosmochim. Acta 46, 1653 (1982).

[82PLU] Plummer, L.N., Busenberg, E., The solubilities of calcite, aragonite, and vaterite in $\mathrm{CO}_{2}-\mathrm{H}_{2} \mathrm{O}$ solutions between 0 and $90^{\circ} \mathrm{C}$, and an evaluation of the aqueous model for the system $\mathrm{CaCO}_{3}-\mathrm{CO}_{2}-\mathrm{H}_{2} \mathrm{O}$, Geochim.

Cosmochim. Acta 46, 1011 (1982).

[82SUL] Sullivan, J.C., Woods, M., Bertrand, P.A., and Choppin, G.R., Radiochim. Acta 31, 45 (1982). 
[84KER] Kerrisk, J.F., Solubility limits on radionuclide dissolution at a Yucca Mountain repository, LA-9995-MS, Los Alamos National Laboratory, Los Alamos, NM, May 1984.

[84KNA] Knauss, K.G., Beiriger, W.J., Report on static hydrothermal alteration studies of topopah spring tuff wafers in J-13 water at $150^{\circ} \mathrm{C}$, UCRL53576, Lawrence Livermore National Laboratory, Livermore, CA, 1984.

[84PAT] Patterson, C.S., Busey, R.H., Mesmer, R.E., Second ionization of carbonic acid in $\mathrm{NaCl}$ media to $250^{\circ} \mathrm{C}$, J. Solution Chem. 13, 647 (1984).

[85KNA1] Knauss, K.G., Beiriger, W.J., Peifer, D.W., Hydrothermal interaction of crushed topopah spring tuff and $\mathrm{J}-13$ water at 90,150 , and $250^{\circ} \mathrm{C}$ using dickson-type, gold-bag rocking autoclaves, UCRL-53630, Lawrence Livermore National Laboratory, Livermore, CA, 1985.

[85KNA2] Knauss, K.G., Beiriger, W.J., Peifer, D.W., Piwinskii, A.J., Hydrothermal interaction of solid wafers of topopah spring tuff with $\mathrm{J}-13$ water and distilled water at 90,150 , and $250^{\circ} \mathrm{C}$ using dickson-type, gold-bag rocking autoclaves, UCRL-53645, Lawrence Livermore National Laboratory, Livermore, CA, 1985.

[85OVE] Oversby, V.M., The reaction of topopah spring tuff with J-13 water at $150^{\circ} \mathrm{C}$ - samples from drill cores USW G-1, USW GU-3, USW G-4, and UE-25h\#1, UCRL-53629, Lawrence Livermore National Laboratory, Livermore, CA, 1985.

[86GLA] Glassley, W.E., Reference waste package environment report, UCRL53726, Lawrence Livermore National Laboratory, Livermore, CA, 1986.

[86KNA] Knauss, K.G., Peifer, D.W., Reaction of vitric topopah spring tuff and J-13 ground water under hydrothermal conditions using dickson-type, gold-bag rocking autoclaves, UCRL-53795, Lawrence Livermore National Laboratory, Livermore, CA, 1986.

[86SMI] Smith, R.W., Popp, C.J., Norman, D.I., The dissociation of oxy-acids at elevated temperatures, Geochim. Cosmochim. Acta 50, 137 (1986).

[87KNA] Knauss, K.G., Beiriger, W.J., Peifer, D.W., Hydrothermal interaction of solid wafers of topopah spring tuff with $\mathrm{J}-13$ water at 90 and $150^{\circ} \mathrm{C}$ using dickson-type, gold-bag rocking autoclaves: long-term experimentș, UCRL53722, Lawrence Livermore National Laboratory, Livermore, CA, 1987.

[88DOE] U.S. Department of Energy, Site characterization plan, Yucca Mountain site, Nevada research and development area, Nevada, DOE/RW-0199, 
Nuclear waste policy act (section 113), Office of civilian radioactive waste management, Washington, D.C., 1988.

[88PAP] Papelis, C., Hayes, K.F., Leckie, J.O., HYDRAQL: a program for the computation of chemical equilibrium composition of aqueous batch systems including surface-complexation modeling of ion adsorption at the oxide/solution interface, Technical report no. 306, Dept. of Civil Engineering, Stanford University, September 1988.

[88SHO] Shock, E.L., Helgeson, H.C., Calculation of the thermodynamic and transport properties of aqueous species at high pressures and temperatures: correlation algorithms for ionic species and equations of state predictions to $5 \mathrm{~kb}$ and $1000^{\circ} \mathrm{C}$, Geochim. Cosmochim. Acta 52, 2009 (1988).

[88ULL] Ullman, W.J., and Schreiner, F., Radiochim. Acta 40, 179 (1986).

[90AHR] Ahrland, S., Hefter, G., Noren, B., A calorimetric study of the mononuclear fluoride complexes of zirconium(IV), hafnium(IV), thorium(IV) and uranium(IV), Acta Chem. Scand. 44, 1 (1990).

[91MEY] Meyer, R.E., Arnold, W.D., The electrode potential of the Tc(IV)-Tc(VII) couple, Radiochim. Acta 55, 19 (1991).

[91SUL] Sullivan, J.C., Choppin, G.R., and Rao, L.F., Calorimetric Studies of $\mathrm{NpO}_{2}{ }^{+}$hydrolysis, Radiochim. Acta 54, 17 (1991).

[92GRE] Grenthe, I., Fuger, J., Konings, R.J.M., Lemire, R.J., Muller, A.B., Nguyen-Trung, C., and Wanner, H., Chemical Thermodynamics of Uranium, North-Holland, Amsterdam, 1992.

[92PAL] Palmer, C.E.A., Silva, R.J., and Miller, C.W., Speciation calculations of $\mathrm{Pu}, \mathrm{Np}, \mathrm{Am}$, and $\mathrm{U}$ in J-13 well water. Effects of anion concentration and $\mathrm{pH}$. Lawrence Livermore National Laboratory, Livermore, CA, draft dated September 1992.

[92SAT] Satoh, I., Choppin, G.R., Interaction of uranyl(VI) with silicic acid, Radiochim. Acta 56, 85 (1992).

[92SLO] Slobodov, A.A., Kritskii, A.V., Zarembo, V.I., Puchkov, L.V., Thermodynamic analysis of the chemical reactions of zirconium with aqueous solutions, Zh. Prikl. Khim. 65, 1031 (1992).

[93LEM] Lemire, R.J., Boyer, G.D., Campbell, A.B., The solubilities of sodium and potassium dioxoneptunium(V) carbonate hydrates at 30,50 , and $75^{\circ} \mathrm{C}$, Radiochim. Acta 61, 57 (1993). 
[93MAR] Martell, A.E, Smith, R.M., Critical stability constants of metal complexes, NIST, October 1993.

[93NEU] Neu, M.P., Coordination chemistry of two heavy metals: I. Ligand preferences in lead(II) complexation, toward the development of therapeutic agents for lead poisoning. II. Plutonium solubility and speciation relevant to the environment, $\mathrm{Ph}$.D. dissertation, University of California, Berkeley, available as LBL-34872, Lawrence Berkeley Laboratory, Berkeley, CA, November 1993.

[93NIT] Nitsche, H., Gatti, R.C., Standifer, E.M., Lee, S.C., Mullaer, A., Prussin, T., Deinhammer, R.S., Maurer, H., Becraft, K., Leung, S., and Carpenter, S.A., Measured solubilities and speciations of neptunium, plutonium, and americium in a typical groundwater (J-13) from the Yucca Mountain region, Milestone Report 3010-WBS 1.2.3.4.1.3.1, LA-12562-MS, Los Alamos National Laboratory, Los Alamos, NM, July 1993.

[95GRE] Grenthe, I., Puigdomenech, I., Sandino, M.C.A., and Rand, M.H., Corrections to the uranium NEA-TDB review, appendix D of Silva, R.J., Bidoglio, G., Rand, M.H., Robouch, P.B., Wanner, H., and Puigdomenech, I., Chemical Thermodynamics of Americium, North-Holland, Amsterdam, 1995.

[95SIL] Silva, R.J., Bidoglio, G., Rand, M.H., Robouch, P.B., Wanner, H., and Puigdomenech, I., Chemical Thermodynamics of Americium, NorthHolland, Amsterdam, 1995.

[95TAI] Tait, C.D., Clark, D.L., Neu, M.P., Ekberg, S.A., and Palmer, P.D., Temperature dependence of the hydrolysis and carbonate complexation reactions of $\mathrm{NpO}_{2}{ }^{+}$, Abstract PA2-02, Migration '95, Saint-Malo, France, September 10-15, 1995.

[96CLA] Clark, D.L., Conradson, S.D., Ekberg, S.A., Hess, N.J., Janecky, D.R., Neu, M.P., Palmer, P.D., and Tait, C.D., A multi-method approach to actinide speciation applied to pentavalent neptunium carbonate complexation, New J. Chem. 20, 211 (1996).

[96PAL] Palmer, C.E.A., Silva, R.J., Bucher, J.J., Thermodynamic data base needs for modeling studies of the Yucca Mountain Project, UCRL-ID-125343, Lawrence Livermore National Laboratory, Livermore, CA, 1996.

[96STU] Stumm, W., and Morgan, J.J., Aquatic Chemistry, 3rd. edition, WileyInterscience, New York, 1996.

[96WRU] Wruck, D.A., Palmer, C.E.A., Silva, R.J., A study of americium(III) carbonate complexation at elevated temperatures by pulsed laser photoacoustic spectroscopy, UCRL-JC-125198, Lawrence Livermore 
National Laboratory, Livermore, CA, 1996; manuscript submitted to Radiochimica Acta.

[97GLA] Glassley, W., Lawrence Livermore National Laboratory, Livermore, CA, ongoing work, Yucca Mountain Project reference water compositions.

[97MOL] Moll, H., Geipel, G., Brendler, V., Bernhard, G., Nitsche, H., Interaction of uranium(VI) with silicon species in aqueous solutions, in Institute of Radiochemistry Annual Report 1996, H. Nitsche, editor, FZR-180, Forschungszentrum Rossendorf e.V., Dresden, Germany, May 1997, p. 10.

[97PUI] Puigdomenech, I., Rard, J.A., Plyasunov, A.V., Grenthe, I., Temperature corrections to thermodynamic data and enthalpy calculations, UCRL-JC126374, Lawrence Livermore National Laboratory, Livermore, CA, January 1997, preprint of chapter 10 of Thermodynamic Modelling of Aqueous Systems, edited by I. Grenthe and I. Puigdomenech, to be published under the sponsorship of the NEA-TDB project.

[97VIA] Viani, B., Lawrence Livermore National Laboratory, Livermore, CA, ongoing work, water passage through EBS materials. 


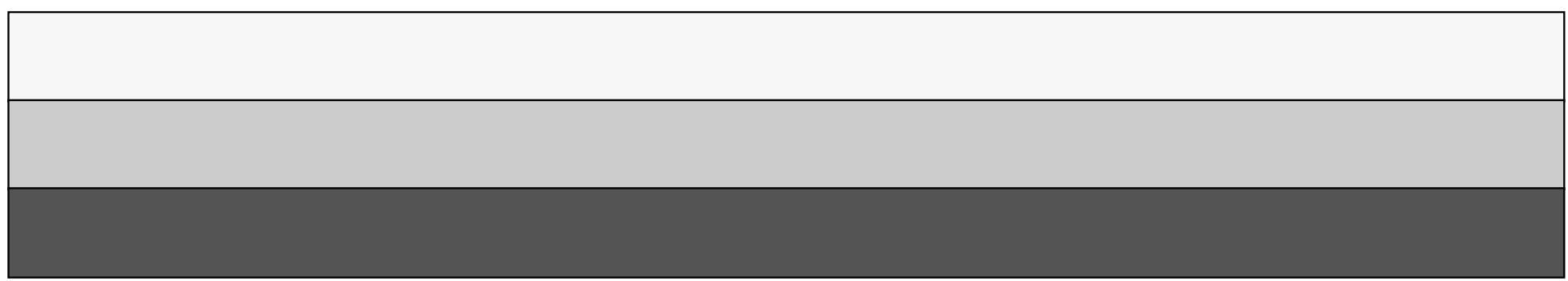

